\title{
D-Hormone analog alfacalcidol: an update on its role in post-menopausal osteoporosis and rheumatoid arthritis management
}

\author{
Florent Richy ${ }^{1,3}$, Rita Deroisy ${ }^{2}$, Marie-Paule Lecart ${ }^{1,2,3}$, Linda Hanssens ${ }^{1,3}$, Audrey Mawet ${ }^{1,3}$, \\ and Jean-Yves Reginster ${ }^{1,2,3}$ \\ ${ }_{1}^{1}$ Public Health, Epidemiology and Health Economics Unit, Faculty of Medicine, University \\ of Liège, Sart-Tilman, ${ }^{2}$ Bone and Cartilage Metabolism Research Unit, University Hospital, Liège, \\ ${ }^{3}$ WHO Collaborating Center for the Public Health Aspects of Osteoarticular Disorders, Liège, Belgium
}

ABSTRACT. Alfacalcidol (1-alpha-hydroxyvitamin $D_{3}$ ) is a non-endogenous analog of vitamin $D$ which can bypass the renal and intestinal regulatory mechanisms that control the production of calcitriol (1,25-hydroxyvitamin $D_{3}$, the active form of vitamin D, D-Hormone). Alfacalcidol may be metabolized into calcitriol with a limited risk of hypercalcemia. Alfacalcidol and calcitriol have been evaluated in animal and human studies assessing their effects on bone mineral density and fracture rates. More recently, they have been shown to produce beneficial effects in muscle, immune system, and autoimmune diseases, including rheumatoid arthritis. This paper discusses the therapeutic efficacy of alfacalcidol in reports in which it has been proposed as an interesting alternative to vitamin $D$ or calcitriol. Some recent findings about general metabolism and regulation of vitamin $D$ and its analogs are discussed. The biological and clinical effects of alfacalcidol in post-menopausal osteoporosis are reviewed, followed by critical appraisal of its efficacy in preventing bone loss and falls in the elderly. The last two sections discuss the role of D-analogs in regulating the immune system, with particular regard to rheumatoid arthritis. The main results of this review show that alfacalcidol may have a wider range of therapeutic applicability, beyond simply restricting it to patients in hemodialysis or peritoneal dialysis with high serum levels of intact $P T H$.

(Aging Clin Exp Res 2005; 17: 133-142)

${ }^{\circ}$ 2005, Editrice Kurtis

\section{INTRODUCTION}

Until 1980, no-one imagined that vitamin $\mathrm{D}$ and its metabolites $25(\mathrm{OH}) \mathrm{D}, 24,25(\mathrm{OH})_{2} \mathrm{D}$ and $1,25(\mathrm{OH})_{2} \mathrm{D}$, well-known for their central roles in calcium and bone metabolism, might play an important role in regulating the immune system. Recent advances in our understanding of their mechanism of action opened up new research fields, due not only to their unique interaction with bone cells but also to their modulation of the immune system. Although alfacalcidol, $1-\alpha(\mathrm{OH}) \mathrm{D}_{3}$, a synthetic D-Hormone analog, has been studied for several decades, its extensive mechanism of action is still not fully elucidated. The aim of this paper was to review the available evidence of the biological and clinical effects of alfacalcidol in post-menopausal osteoporosis (PMOP) and rheumatoid arthritis (RA).

\section{GENERAL METABOLISM OF VITAMIN D AND ITS ANALOGS (FIGS. 1-2)}

Vitamins $\mathrm{D}_{2}$ (ergocalciferol) and $\mathrm{D}_{3}$ (cholecalciferol) are produced by the skin or absorbed from the gut. They are metabolized into their active form, calcitriol, by two successive steps: 25-hydroxylation in the liver to $25(\mathrm{OH}) \mathrm{D}$, followed by $1 \alpha$-hydroxylation in the renal proximal tubules to $1,25-(\mathrm{OH})_{2} \mathrm{D}$, yielding the biologically active form of vitamin D, calcitriol (1). Some other cells exhibit $1 \alpha$-hydroxylase activity, including osteoblasts, placental cells, keratinocytes, macrophages and some tumor cells. The role of the extrarenal production of $1,25(\mathrm{OH})_{2} \mathrm{D}$ is still debated but, in normal conditions, it does not significantly contribute to the circulating levels of the hormone $(2,3)$. 24-hydroxylation, producing 24,25 -dihydroxyvitamin $\mathrm{D}\left[24,25(\mathrm{OH})_{2} \mathrm{D}\right]$ or $1,24,25$-trihydroxyvitamin $\mathrm{D}$, occurs in a wide range of normal tissues and is believed to be important both to catabolise vitamin $\mathrm{D}$ metabolites and to regulate the active forms of vitamin $\mathrm{D}(4) .24,25(\mathrm{OH})_{2} \mathrm{D}$ is not in fact inactive. Recent animal studies have shown that this

Key words: Alfacalcidol, osteoporosis, rheumatoid arthritis.

Correspondence: F. Richy, PhD, University of Liège, CHU B23, B4000 Sart-Tilman, Belgium.

E-mail: florent.richy@ulg.ac.be

Received July 30, 2004; accepted in revised form December 7, 2004.

Aging Clin Exp Res, Vol. 17, No. 2133 


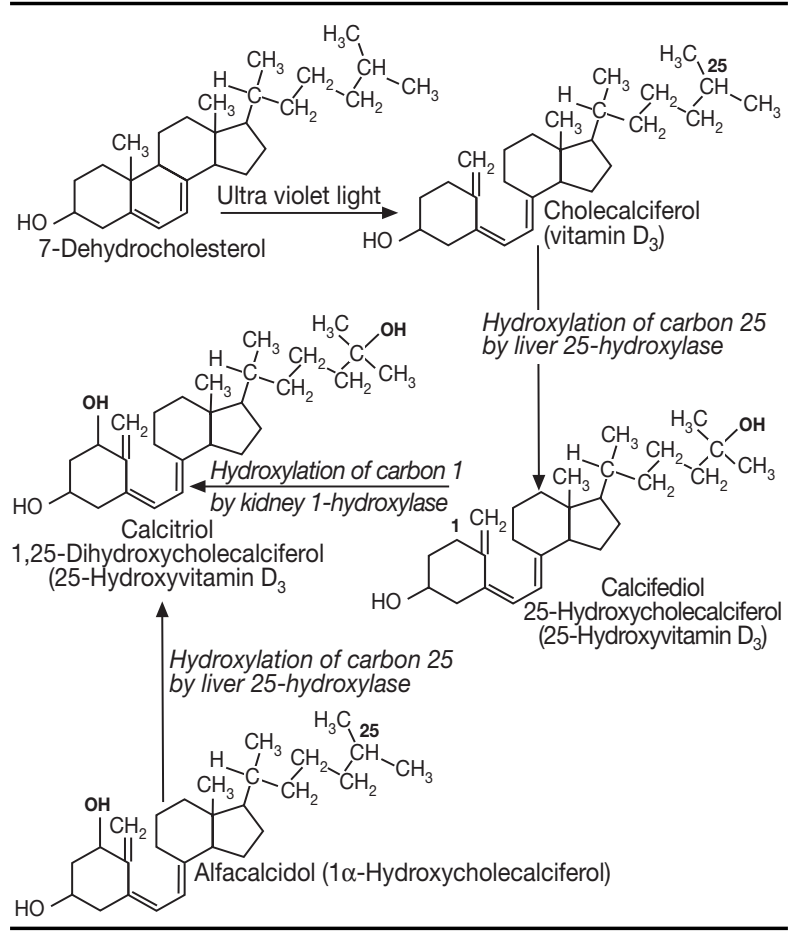

Figure 1 - General vitamin D pathways.

metabolite can stimulate chondrocyte maturation (5), increase bone mineral density in vitamin $\mathrm{D}$-replete rats, rabbits and dogs (6), and play a beneficial role in fracture repair in chicks (7). $24,25(\mathrm{OH})_{2} \mathrm{D}$ has also been shown to be a potent inhibitor of PTH secretion in humans (8). The interactions among calcitriol, alfacalcidol and $24,25(\mathrm{OH})_{2} \mathrm{D}$ are still under study. Recent findings in animal models suggest that both metabolites must be present for optimal changes in bone metabolism (Fig. 2). The major enzymes involved in vitamin $D$ hydroxylation are mitochondrial mixed-function oxidases containing cytochrome P450 with ferredoxin and hemebinding domains (9). Until today, four cytochrome P450 molecular species (CYP27A1, CYP2C11, CYP2D25, CYP3A4) have been identified as vitamin $\mathrm{D}_{3}$ 25-hydroxylases $(10,11)$. Alfacalcidol $\left(1-\alpha(\mathrm{OH}) \mathrm{D}_{3}\right)$ is a synthetic derivate of vitamin $\mathrm{D}$. Important for its metabolization is the fact that hepatic 25-hydroxylation is unregulated and exclusively substrate-dependent. Conversely, the renal $1 \alpha$-hydroxylase enzyme is stringently regulated by: the PTH cAMP-mediated pathway, calcitonin in a different region of the proximal tubule, and by $1,25(\mathrm{OH})_{2} \mathrm{D}$ itself, through negative feedback regulation via its receptor (VDR) $(2,4)$. Thus, in situations in which the general vitamin $\mathrm{D}$ pathways are disturbed, exogenous alfacalcidol may bypass these regulatory systems to produce bioavailable calcitriol. Circulating vitamin $\mathrm{D}$ metabolites measured in clinical practice are $25(\mathrm{OH}) \mathrm{D}$ and $1,25(\mathrm{OH})_{2} \mathrm{D}$ (calcitriol). As $25(\mathrm{OH}) \mathrm{D}$ synthesis is substrate-, i.e., vitamin $\mathrm{D}$-dependent, serum levels of this metabolite are taken as a measure of vitamin D status. Besides its classical actions in calcium metabolism, it is now suggested that the hormonal form of vitamin D has many "uncommon" functions, which have only been revealed as a result of the identification and characterization of its receptor. The VDR complex was discovered in 1975 (12). Many tissues express VDR, including osteoblasts, intestinal, muscle, distal renal, liver, parathyroid, and T-cells and monocytes $(13,14)$. Calcitriol functions as a steroid hormone which binds to a cytosolic VDR, resulting in selective demasking of the genome of the nucleus (Fig. 3).

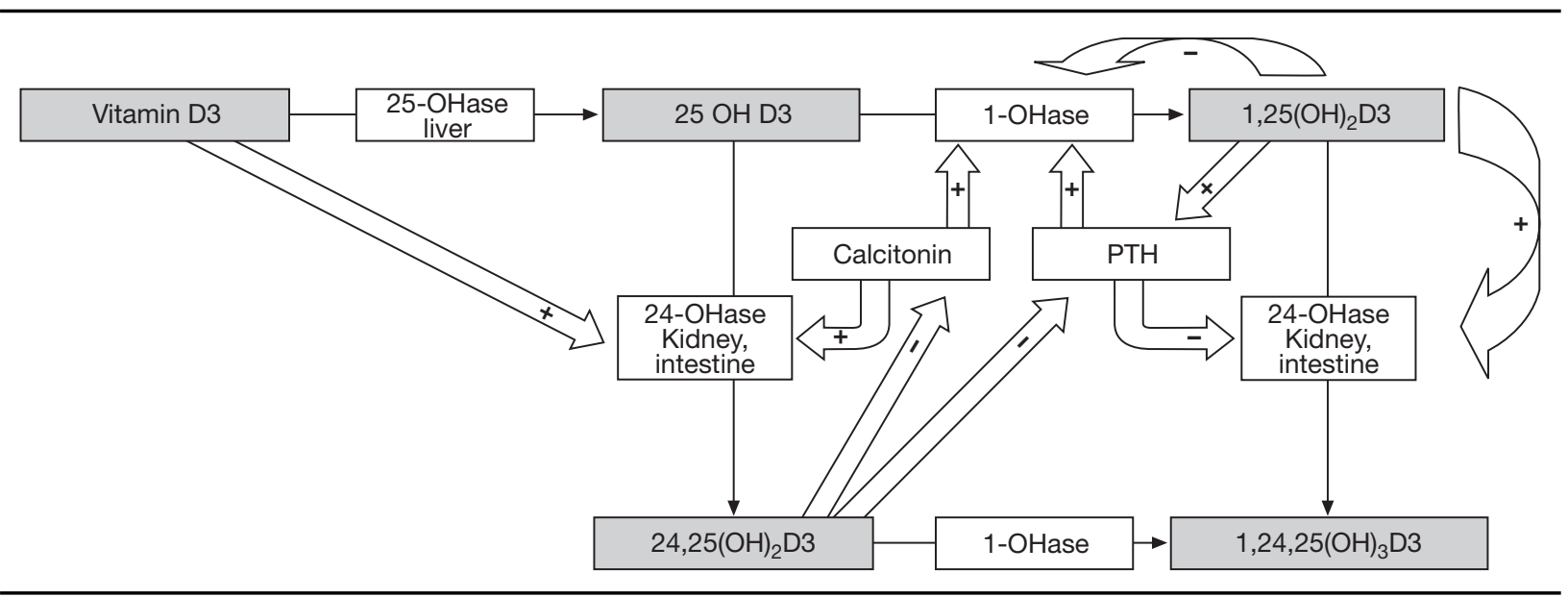

Figure 2 - Regulation of vitamin $D$ metabolism.

OHase: OH-hydroxylase. 


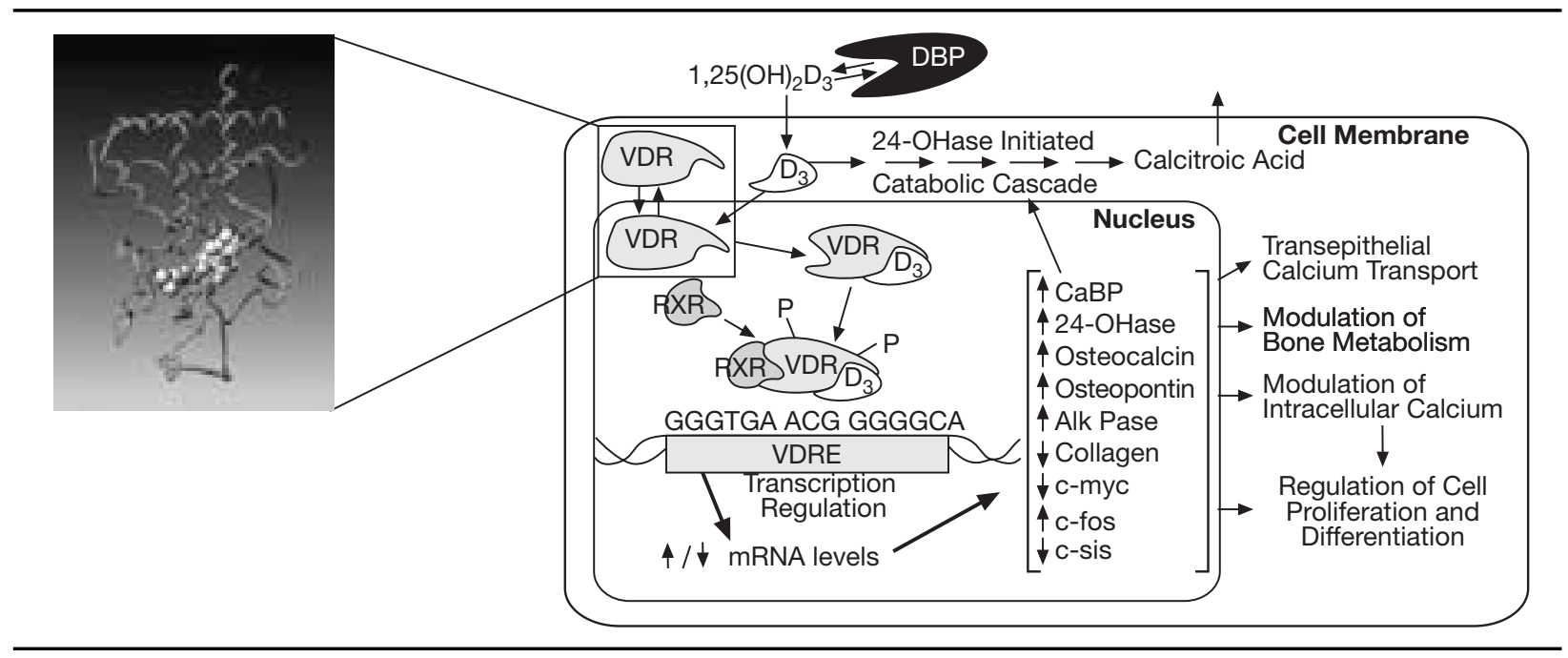

Figure 3 - Vitamin D Receptor: structure and function.

$D B P$ : vitamin D binding protein; VDRE: vitamin D responsive elements (specific DNA sequences); CaBP: calcium-binding protein; 24-OHase: 24-OH-hydroxylase; Alk Pase: Alkaline phosphatase; c-myc, c-fos, $c$-sis: protooncogen regulating cell proliferation and differentiation; RXR: Retinoid X Receptor

Two subtypes of VDR have recently been discovered using knock-out mice models. $1 \alpha, 25(\mathrm{OH})_{2} \mathrm{D}(3)$-dependent regulation of DNA synthesis in chondrocytes requires the presence of the 1,25-nVDR, although other physiological responses to the vitamin $\mathrm{D}$ metabolite, such as proteoglycan sulfating, involve regulation via the $1,25-\mathrm{mVDR}(5)$. Because of the wide variety of tissues in which VDR has been identified, the exploitation of vitamin D compounds in treating various diseases has been expanded.

\section{VITAMIN D DEFICIENCY: \\ A HETEROGENEOUS CONDITION}

"Vitamin D deficiency" collectively describes a number of pathological conditions which include primary vitamin D deficiency, calcitriol deficiency, and resistance to calcitriol. Primary vitamin D deficiency is due to inadequate dietary intake or exposure to sunlight, and is not simply a biochemical abnormality. It is regularly associated with secondary hyperparathyroidism, increased bone turnover, bone loss, osteoporosis, and increased risk of fracture (15). Vitamin D deficiency impairs the intestinal absorption of calcium. PTH maintains normal serum calcium levels for a time, despite decreased calcium absorption, by increasing bone resorption; however, vitamin D deficiency progressively causes resistance to the osteoclastic effects of PTH on bone and a decrease in calcium renal tubular reabsorption (16). PTH increases serum calcium but also stimulates phosphaturia, resulting in hypophosphatemia (16). These combined effects lead to a reduced bone mineralization. Unlike primary vitamin D deficiency, pri- mary calcitriol deficiency is not due to the limitation of precursors but to a defect in the synthesis of calcitriol, reducing intestinal $\mathrm{Ca}$ absorption and increasing PTH and bone resorption. The pathogenesis of primary calcitriol deficiency is related to impaired ability of the kidney to synthesize adequate amounts of calcitriol. It is common in patients with renal insufficiency or failure. Resistance to calcitriol is related to aging-associated decline in the functions of various tissues and organs, leading to reduced calcitriol biological action despite its normal serum levels (17). The potential cause of this resistance may be due to agerelated or unknown defects in regulation in the number or a decrease in the affinity of VDR, which mediate genomic actions of vitamin $\mathrm{D}(18,19)$.

\section{BIOLOGICAL EFFECTS OF ALFACALCIDOL IN POST-MENOPAUSAL OSTEOPOROSIS}

Alfacalcidol is a synthetic precursor of calcitriol, and is converted into $1,25(\mathrm{OH})_{2} \mathrm{D}_{3}$, predominantly in the liver, by 25-hydroxylation. 25-hydroxylation has been reported to be catalyzed by both mitochondrial CYP27A and a microsomal CYP2D25 vitamin $\mathrm{D}_{3}$ 25-hydroxylase in the liver $(20,21)$. Northern blotting and reverse transcriptionpolymerase chain reaction experiments have revealed that porcine CYP2D25 mRNA (showing 77\% identity with that of humans) is expressed at the highest level in the liver and in small amounts in other tissues, including muscle (20) and bone. As noted above, alfacalcidol bypasses endogenous regulation by renal $1-\alpha$ hydroxylase and its pharmacokinetic profile is therefore very different from that of calcitriol: after oral ingestion of calcitriol, peak 
serum $1,25(\mathrm{OH})_{2} \mathrm{D}_{3}$ is reached within 2 hours, whereas oral ingestion of alfacalcidol causes a slow rise in serum calcitriol with peak values after 8-18 hours. Calcitriol, upon absorption, acts immediately and directly on the VDR in the intestinal mucosal cells to promote Ca absorption, leading to a rapid increase in serum calcium. In contrast, alfacalcidol has very limited intestinal action, since 25-hydroxylase required for its metabolization into calcitriol acts predominantly in the liver. Compared with calcitriol, alfacalcidol allows for more progressive and longer production of calcitriol together with a lower risk of hypercalcemia. This allows the lack of calcium absorption due to VDR deficiency to be counterbalanced.

It has been suggested (22) that pharmacological or suprapharmacological doses of $1,25(\mathrm{OH})_{2} \mathrm{D}(3)$ stimulate bone resorption by inducing RANKL, the ligand from pre-osteoblastic cells binding to RANK on pre-osteoclastic cells to promote the differentiation of osteoclasts (23). Conversely, a certain range of physiological doses of vitamin D inhibit PTH-induced bone resorption, the latter mechanism appearing to be mediated, at least partly, by suppression of PTH/PTHrP receptor-mediated signaling. This may highlight the central role played by $1,25(\mathrm{OH})_{2} \mathrm{D}_{3}$ in bone formation and resorption coupling. Indeed, the most important endocrine regulator of PTH is calcitriol (24), which regulates PTH through its receptor by suppressing both the expression of the preproparathyroid gene and parathyroid cell proliferation (25). Alfacalcidol, by enhancing D-analog levels, indirectly suppresses secondary hyperparathyroidism, which is common in osteoporotic and elderly patients. The mechanism includes inhibition of the proliferation of parathyroid cells by reducing their apoptosis $(26,27)$ as well as PTH synthesis and release (28), and of the effects of PTH on bone $(29,30)$. Reduction of alkaline phosphatase activity has also been shown (31). Vitamin D metabolites calcitriol and $24,25(\mathrm{OH})_{2} \mathrm{D}$ modulate the response of bone and cartilage cells to 17 beta-estradiol and dihydrotestosterone in both cell cultures and in vivo rat models (32). They both reduce, by one order of magnitude, the amount of sex steroids needed to stimulate cultured osteoblast-like cells or rat embryo epiphyseal cartilage cells, and synergistically increase the maximal response of these cells (32). Notwithstanding this, it has been shown that interactions among Danalogs, VDR and oestrogen receptor (ER) are largely dependent on gender groups, suggesting complex ERVDR-sex, ER-age-sex and VDR-age-sex interactions may exist (33). The current data do not support the strong role of $24,25(\mathrm{OH})_{2} \mathrm{D}$ alone in the regulation of osteoblast action and mineralization (34). Conversely, alfacalcidol induces an increase in calcitonin secretion (35) and normalization of uncoupled bone turnover through an increase in transforming growth factor beta (TGF-beta), which stimulates osteoblastic maturation, and osteoprotegerin, which inhibits osteoclastic maturation by inhibiting the RANKL-RANK system (36). Calcitriol, by inhibiting bone-resorbing cytokines, specifically TNF-alpha or osteoblastic apoptosis, induces a modification in osteoclastic apoptosis, and an impact on the remodeling process has been observed (37). Correction of the helper/suppressor ratio in patients with high bone loss due to an increase in CD8 also appears to be involved (38).

\section{CLINICAL EFFECTS OF ALFACALCIDOL IN POST-MENOPAUSAL OSTEOPOROSIS}

Several studies have investigated the clinical effects of D-analogs (mainly calcitriol, alfacalcidol and $24,25(\mathrm{OH})_{2} \mathrm{D}$ ) on bone mineral density, fractures and bone metabolism markers in PMOP. $24,25(\mathrm{OH})_{2} \mathrm{D}$ is still a poorly studied compound, which has not shown any beneficial effects on BMD and calcium metabolism in clinical studies (34).

We previously performed two meta-analyses reviewing the clinical effects of D-analogs calcitriol and alfacalcidol (39), and compared their efficacies against that of native vitamin D (40). Our first systematic review included all randomized controled trials on alfacalcidol or calcitriol versus calcium or placebo. Eight studies of alfacalcidol (41-48) and a similar number of studies of calcitriol (49-56) specifically focused on their respective clinical efficacies on bone loss and/or fracture. Among trials of alfacalcidol, four (41-44) investigated post-menopausal osteoporosis in women aged 60 and more. Meta-analysis of these studies revealed the highly significant effect of alfacalcidol on global and particularly on spinal BMD, at a median duration of 18 months. Regarding non-spinal BMD, the data were too sparse for a proper meta-analysis. Regarding fracture prevention, we found a highly significant reduction $(-47 \%)$ in the relative risk of lumbar spine fractures in the alfacalcidol arms, compared with placebo or calcium alone, at a median follow-up of 12 months. We were not able to find relevant data on hip fracture prevention by alphacalcidol in PMOP. However, we did find a trend toward increased efficacy of alfacalcidol, compared with calcitriol, in preventing decrease with $\mathrm{BMD}$, and more specifically spinal BMD. In addition, studies on alfacalcidol, pooled together, provided remarkably homogenous results ( $p_{\text {heterogeneity }}=0.66$ ); studies on calcitriol did not ( $p_{\text {hetero- }}$ geneity $=0.01$ ). These results suggested not only that alfacalcidol and calcitriol have similar efficacies, but also that alfacalcidol may exert its BMD-preserving capabilities in a wider range of clinical patterns.

Our second quantitative review (40) assessed the relative efficacies of $\mathrm{D}$-analogs alfacalcidol and calcitriol against their parent compound, vitamin D. Regarding BMD, D-analogs exerted a significantly higher efficacy on $\mathrm{BMD}$ at any site compared with native vitamin $\mathrm{D}$, at a median duration of 24 months. When restricted to the lum- 
bar spine, this intertreatment difference remained significant whereas there were no significant differences regarding their efficacies on other measurement sites, including hip. When comparing the adjusted global relative risks for spinal and non-spinal fracture, alfacalcidol and calcitriol appeared to be significantly more effective approaches compared with vitamin D. Analysis of the difference between spinal and non-spinal fracture rates confirmed the benefits of D-analogs, with significantly lower spinal and non-spinal fracture rates for D-analogs, on the basis of 30 to 36 months follow-up. Despite the lack of head-to-head trials in this field and the need for more careful follow-up of calcemia, alfacalcidol may be considered as an interesting alternative to native vitamin $\mathrm{D}$ in preventing bone loss and fractures in PMOP.

\section{ALFACALCIDOL AND MUSCULAR FUNCTION}

Muscle function, together with bone mineral density, is an important determinant of fracture risk, especially in the elderly (57). It was assumed for a century that vitamin D deficiency was linked to disturbed muscle metabolism (58). Vitamin D deficiency can impair intracellular Ca metabolism in muscle cells. The Ca-depleted content of mitochondria isolated from vitamin D-depleted chicks has been shown to be low (59), and Ca uptake into the sarcoplasmic reticulum is reduced during vitamin D deficiency $(60,61)$. Animal studies have shown that the actinomyosin content of myofibrils is reduced during experimental rickets (62).

Several studies in humans have demonstrated the relationship between D-hormone analogs and muscle function (63-65). Patients with osteomalacia suffer from muscle weakness and have low serum levels of muscle enzymes (66). A recent study on chick embryonic muscle cells provided direct evidence for the participation of the VDR in non-genomic $1,25(\mathrm{OH})_{2} \mathrm{D}_{3}$ signal transduction. Activation of tyrosine phosphorylation cascades through this mechanism may contribute to hormone regulation of muscle growth (67). The results of a prospective, population-based study showed that lower 25-OHD and higher PTH levels increase the risk of sarcopenia in older men and women (68). A recent study has shown that congestive heart failure is associated with low vitamin D status (69).

Several trials have provided evidence for the involvement of D-analogs in preserving muscle function. Supplementation with 357 or $1250 \mu \mathrm{g}$ vitamin D or $50 \mu \mathrm{g}$ 25(OH)D for 1 or 2 months normalized muscle strength in patients with myopathy $(66,70)$. Leg extension power was positively correlated with serum $25(\mathrm{OH}) \mathrm{D}$ levels in elderly males and with serum $1,25(\mathrm{OH})_{2} \mathrm{D}_{3}$ in the whole group of males and females (64). Grady et al. (71) and Lips et al. (72) did not show statistical improvement in muscle function using calcitriol or vitamin D. Glerup et al.
(73), Pfeifer et al. (74), and Bischof et al. (75) showed a significant decrease in body sway and number of falls, corresponding to an improvement in muscle function using native vitamin $\mathrm{D}$.

More recently, research has focused on alfacalcidol. Dukas et al. (76) demonstrated that, in calcium-replete patients, alfacalcidol treatment significantly and safely reduced the number of fallers in an elderly community-dwelling population (OR 0.45, 95\% CI 0.21-0.97, $p=0.042$ ). Sato et al. (44) reported a highly significant differential efficacy of alfacalcidol on BMD depending on body side, in hemiplegic patients. BMD on the intact side increased by $3.5 \%$, but decreased by $2.4 \%$ on the hemiplegic side over 6 months. Some local factors, such as paralysis and immobilization, may diminish the effect of alfacalcidol on bone formation on the hemiplegic side. This is an argument favoring the involvement of muscle 25-hydroxylase, which converts alfacalcidol into active calcitriol on a local basis. Janssen et al. (77) assessed the effects of alfacalcidol in vitamin D-deficient elderly people. Muscle strength improved, as well as walking distance and functional ability, which resulted in a reduction in the number of falls and fractures. Additional research is needed to clarify further to what extent alfacalcidol supplementation can preserve muscle strength and prevent falls and fractures in elderly people.

\section{IMMUNOLOGICAL ROLE OF ALFACALCIDOL (FIG. 4)}

In recent years, there has been an effort to understand the possible non-calcemic roles played by vitamin $\mathrm{D}$, including its role in the immune system and, in particular, on T-cell-mediated immunity. Vitamin D receptor is in fact found in significant concentrations in T-lymphocytes and macrophage populations $(78,79)$, but its highest concentration is found in immature immune cells of the thymus and mature CD-8 T lymphocytes (80). Calcitriol has recently aroused great interest as an immune modulator with immunosuppressive activity, because of its

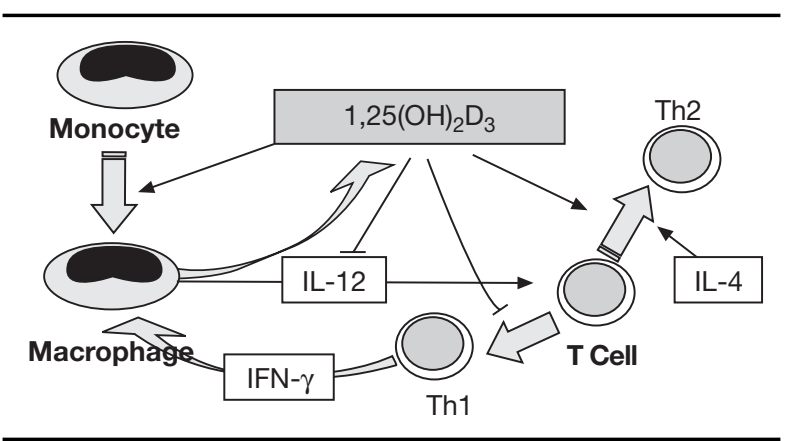

Figure 4 - Interactions between calcitriol and the immune system. Pietschmann et al. Bedeutung von Vitamin D im Immunsystem. Journal Für Mineralstoffwechsel 2003; 10: 13-15. Reproduced by kind permission of Krause \& Pachernegg GMBH. 
ability to shift T-cell responses from Th1 to Th2. The hormone inhibits the production of lymphokines (IL-2, IFNgamma) and monocyte-derived cytokine (IL-12), leading to inhibition of helper T-cell subset type 1 (Th1) $(81,82)$. The significant role of vitamin $\mathrm{D}$ compounds as selective immunosuppressants is illustrated by their ability to prevent or even suppress animal models of autoimmune disease. Several studies on animal models have shown that 1,25-dihydroxyvitamin has a significant impact on the development of encephalomyelitis (83), rheumatoid arthritis (84), systemic lupus erythematosus (85), type I diabetes (86), and inflammatory bowel disease (87). Possible mechanisms of suppression of these autoimmune disorders by calcitriol have been presented. Notably, calcitriol stimulates transforming growth factor TGFß-1 (88) and interleukin production which, in turn, may suppress inflammatory T-cell activity. In support of this, calcitriol was unable to suppress a murine model of human multiple sclerosis in IL-4-deficient mice (80). It was shown to suppress proliferation of promyelocytes and promote their differentiation into monocytes (89). Peripheral lymphocytes contain variable amounts of VDR. CD-8 lymphocytes have the highest concentrations, whereas CD-4 and macrophages have lower ones (90).

The intrinsic effects of alfacalcidol, i.e., not those from its metabolite calcitriol, on various immunological parameters including lymphocyte subsets are still not clearly demonstrated. However, interestingly, Yamauchi et al. (91) showed that, in patients with rheumatoid arthritis, the CD-4/CD-8 ratio remains stable in patients whose initial value was normal, whereas it decreases after alfacalcidol treatment in patients whose initial values were abnormally high. It has been demonstrated that the delayed hypersensitivity response to dinitrobenzene is impaired in vitamin D deficient mice (92), which tends to confirm the modulator control of $1,25-(\mathrm{OH})_{2} \mathrm{D}_{3}$ in T cell-mediated immunity. The T-cell immune response depending on $D$ hormone levels displays a characteristic inverted " $U$ " curve (93). While this field requires more research investment, this particular activity of $\mathrm{D}$-hormone analogs is the rationale for studies and trials on alfacalcidol and calcitriol for treating autoimmune disorders, including RA.

\section{ALFACALCIDOL IN RHEUMATOID ARTHRITIS}

Patients with RA are at high risk of developing both generalized and periarticular osteoporosis (94) and are thus at even higher risk of fractures (95). Local and systemic osteoporosis are linked to increased production of inflammatory cytokines (TNF alpha, IL-1 beta, IL-6), resulting in increased formation and activation of osteoclasts (96-100). TNF-alpha may also interfere with bone formation by promoting apoptosis of osteoblasts (101). Bone loss appears very early and is correlated directly with disease activity (102). Later in the process, it is associated with the negative effects of limited mobility, which may be related to decreased muscle function in the elderly. Goertz et al. (103) and Lee et al. (104) showed that VDR polymorphisms do not play a major role in RA predisposition, but Gough et al. (105) did obtain inverse results in female patients with early RA. In parallel, predisposition towards osteoporosis has been shown in certain VDR genotypes (106). High disease activity in patients with RA has been associated with alterations in vitamin $\mathrm{D}$ metabolism and increased bone resorption (84). The decrease in $1,25(\mathrm{OH})_{2} \mathrm{D}_{3}$ levels in these patients may lead to a negative calcium balance and inhibition of bone formation. Furthermore, low levels of $1,25(\mathrm{OH})_{2} \mathrm{D}_{3}$ may raise levels of activated Tcells and proliferation of lymphokine-activated killer cells, thus accelerating the arthritic process (107).

Whether glucocorticoids work positively or negatively on generalized/periarticular osteoporosis in RA is still controversial (108-110). The pathogenesis of corticosteroid-induced osteoporosis is complex. As a pathogenetic co-factor, corticosteroids reduce intestinal calcium absorption and increase renal calcium excretion, resulting in compensatory increased PTH release and increased sensitivity of bone to PTH. In addition, corticosteroids inhibit osteoblastic function (111) as well as the favorable effects of growth factors and sex hormones on bone $(112,113)$. Thus, bone loss in RA is centered around primary inhibition of osteoblastic activity, compounded by the effects of secondary hyperparathyroidism (114). It has recently been suggested that the expression of D-hormone receptors (VDR) may be decreased by corticosteroids, and that they probably reduce the number of functional VDR $(115,116)$. This may be an explanation for the efficacy of D-analogs in treating PMOP. Corticosteroids inhibit IL-12 production in human monocytes and enhance their capacity to induce IL-4 synthesis in CD4+ lymphocytes (117).

$\mathrm{D}$-analogs have been shown to inhibit cytokines IL-1, IL-6, TNF-alpha and particularly IL-12 (118). At the cellular level, D-hormone may directly or indirectly reduce the expression of Th1 helper cells by inhibition of IL-12 from monocytes (119). Therapy with alfacalcidol or calcitriol results in increased production of Th2 helper cells, which produce bone-protective cytokines like IL-4 and IL-10 (120). D-analogs have been shown to have a protective effect on osteoblasts against TNF-alpha-induced cell death (101).

Five intervention trials aimed at quantifying the effect of vitamin $\mathrm{D}$ and its metabolites on the clinical expression of RA have been published. Andjelkovic et al. (121) (alfacalcidol $2 \mu \mathrm{g} /$ day $/ 3$ months), Brohult et al. (122) (vitamin D $2500 \mu \mathrm{g} /$ day $/ 1-2$ years) and Dottori et al. (123) (25(OH)D $50 \mu \mathrm{g} /$ day/1 month) have shown reductions in disease activity or pain symptoms, whereas Yamauchi et al. (124) (alfacalcidol $2 \mu \mathrm{g} /$ day/4 months) 
and Hein et al. (125) (alfacalcidol $1 \mu \mathrm{g} /$ day/2 months) have not. With respect to these contradictory findings, the exact role of alfacalcidol in the management of RA remains unclear.

Various clinical studies have investigated the efficacy of alfacalcidol in corticosteroid-induced bone loss, regardless of the underlying disease. The main results of its use in RA have been to preserve bone mass, not to increase it (126). Gukasian et al. (127) reported an analysis of the anti-osteoporotic efficacy of alfacalcidol in 50 patients with RA. $30 \mathrm{RA}$ patients received alfacalcidol (0.75-1.0 $\mathrm{\mu g} /$ day) for 12 months and 20 control RA patients received a placebo. Alfacalcidol stabilized bone mineral density at the femoral neck and lumbar spine. A significant BMD increase was observed in those areas of the proximal femur where cortical bone tissue prevails. In a double-blind, placebo-controlled comparative trial of 16 weeks by Yamauchi et al. (91), 1.0-2.0 $\mu \mathrm{g} /$ day alfacalcidol revealed $10 \%$ more patients with improvement compared with the placebo group, but the difference between them did not reach significance. The OKT4/OKT-8 ratio was found not to change in patients whose initial value was normal, whereas it decreased after alfacalcidol treatment in patients whose initial values were higher. Bone mineral density was conserved in the alfacalcidol group. Among all trials, taking efficacy on bone loss into consideration, a dose of $1.0 \mu \mathrm{g}$ /day was judged to be suitable for safe, long-term treatment with regard to the limited risk of hypercalcemia.

\section{REFERENCES}

1. Stokstad E. Nutrition. The vitamin D deficit. Science 2003; 302: 1886-8

2. Takeyama K, Kitanaka S, Sato T, Kobori M, Yanagisawa J, Kato S. 25-Hydroxyvitamin D3 1alpha-hydroxylase and vitamin D synthesis. Science 1997; 277: 1827-30.

3. Fu GK, Portale AA, Miller WL. Complete structure of the human gene for the vitamin D 1 alpha-hydroxylase, P450c1alpha. DNA Cell Biol 1997; 16: 1499-507.

4. St-Arnaud R, Arabian A, Travers R, et al. Deficient mineralization of intramembranous bone in vitamin D-24-hydroxylase-ablated mice is due to elevated 1,25-dihydroxyvitamin $\mathrm{D}$ and not to the absence of 24,25-dihydroxyvitamin D. Endocrinology 2000; 141: 2658-66.

5. Boyan BD, Sylvia VL, McKinney N, Schwartz Z. Membrane actions of vitamin D metabolites 1alpha,25(OH)2D3 and $24 \mathrm{R}, 25(\mathrm{OH}) 2 \mathrm{D} 3$ are retained in growth plate cartilage cells from vitamin D receptor knockout mice. J Cell Biochem 2003; 90: $1207-23$

6. Tanaka H. Vitamin D metabolites and bone. In: Feldman D, Glorieux FH, Pike JW, eds. Vitamin D. Academic Press, San Diego 1997: 305-12.

7. Seo EG, Norman AW. Three-fold induction of renal 25-hydroxyvitamin D3-24-hydroxylase activity and increased serum 24,25dihydroxyvitamin D3 levels are correlated with the healing process after chick tibial fracture. J Bone Miner Res 1997; 12: 598-606.

8. Carpenter TO, Keller M, Schwartz D, et al. 24,25 Dihydroxyvitamin D supplementation corrects hyperparathyroidism and im- proves skeletal abnormalities in X-linked hypophosphatemic rickets- a clinical research center study. J Clin Endocrinol Metab 1996; 81: 2381-8.

9. Jones G, Ramshaw H, Zhang A, et al. Expression and activity of vitamin D-metabolizing cytochrome P450s (CYP1alpha and CYP24) in human nonsmall cell lung carcinomas. Endocrinology 1999; 140: 3303-10.

10. Yamasaki T, Izumi S, Ide H, Ohyama Y. Identification of a novel rat microsomal vitamin D3 25-hydroxylase. J Biol Chem 2004; 279: 22848-56.

11. Gupta RP, Hollis BW, Patel SB, Patrick KS, Bell NH. CYP3A4 is a Human Microsomal Vitamin D 25-Hydroxylase. J Bone Miner Res 2004; 19: 680-8.

12. Kream BE, Reynolds RD, Knutson JC, Eisman JA, DeLuca HF. Intestinal cytosol binders of 1,25-dihydroxyvitamin D and 25-hydroxyvitamin D. Arch Biochem Biophys 1976; 176: 779-87.

13. DeLuca HF. New concepts of vitamin D functions. Ann NY Acad Sci USA 1992; 669: 59-68.

14. Zittermann A. Vitamin D in preventive medicine: are we ignoring the evidence? Br J Nutr 2003; 89: 552-72.

15. Ooms ME, Lips P, Roos JC, et al. Vitamin D status and sex hormone binding globulin: determinants of bone turnover and bone mineral density in elderly women. J Bone Miner Res 1995; 10: 1177-84.

16. Beckerman P, Silver J. Vitamin D and the parathyroid. Am J Med Sci 1999; 317: 363-9.

17. Lau KH, Baylink DJ. Vitamin D therapy of osteoporosis: plain vitamin $\mathrm{D}$ therapy versus active vitamin $\mathrm{D}$ analog (D-hormone) therapy. Calcif Tissue Int 1999; 65: 295-306.

18. Christakos S, Raval-Pandya M, Wernyj RP, Yang W. Genomic mechanisms involved in the pleiotropic actions of 1,25-dihydroxyvitamin D3. Biochem J 1996; 316 (Pt 2): 361-71.

19. Kinyamu HK, Gallagher JC, Prahl JM, DeLuca HF, Petranick KM, Lanspa SJ. Association between intestinal vitamin D receptor, calcium absorption, and serum 1,25 dihydroxyvitamin D in normal young and elderly women. J Bone Miner Res 1997; 12: $922-8$.

20. Hosseinpour F, Wikvall K. Porcine microsomal vitamin D(3) 25hydroxylase (CYP2D25). Catalytic properties, tissue distribution, and comparison with human CYP2D6. J Biol Chem 2000; 275: 34650-5

21. Hosseinpour F, Ibranovic I, Tang W, Wikvall K. 25-Hydroxylation of vitamin D3 in primary cultures of pig hepatocytes: evidence for a role of both CYP2D25 and CYP27A1. Biochem Biophys Res Commun 2003; 303: 877-83.

22. Ueno Y, Shinki T, Nagai Y, Murayama H, Fujii K, Suda T. In vivo administration of 1,25-dihydroxyvitamin D3 suppresses the expression of RANKL mRNA in bone of thyroparathyroidectomized rats constantly infused with PTH. J Cell Biochem 2003; 90: 267-77.

23. Kwan Tat S, Padrines M, Theoleyre S, Heymann D, Fortun Y. IL6, RANKL, TNF-alpha/IL-1: interrelations in bone resorption pathophysiology. Cytokine Growth Factor Rev 2004; 15: 49-60.

24. Alvarez-Hernandez D, Naves M, Santamaria I, Menarguez J, Torregrosa V, Cannata J. Response of parathyroid glands to calcitriol in culture: is this response mediated by the genetic polymorphisms in vitamin D receptor? Kidney Int Suppl 2003; 85: S19-22.

25. Slatopolsky E, Brown AJ. Vitamin D and its analogs in chronic renal failure. Osteoporos Int 1997; 7 (Suppl 3): S202-8.

26. Ledger GA, Burritt MF, Kao PC, O'Fallon WM, Riggs BL, Khosla $\mathrm{S}$. Abnormalities of parathyroid hormone secretion in elderly 
women that are reversible by short term therapy with 1,25-dihydroxyvitamin D3. J Clin Endocrinol Metab 1994; 79: 211-6.

27. Parfitt AM. The hyperparathyroidism of chronic renal failure: a disorder of growth. Kidney Int 1997; 52: 3-9.

28. Gallacher SJ, Cowan RA, Fraser WD, Logue FC, Jenkins A, Boyle IT. Acute effects of intravenous 1 alpha-hydroxycholecalciferol on parathyroid hormone, osteocalcin and calcitriol in man. Eur J Endocrinol 1994; 130: 141-5.

29. Shiraishi A, Higashi S, Okawa $H$. The effect of $1-\mathrm{a}(\mathrm{OH}) \mathrm{D} 3$ on bone metabolism in parathyroidectomized rats with continuous PTH perfusion. Osteoporos Int 1997; 7: 35.

30. Suda T, Takahashi N, Martin TJ. Modulation of osteoclast differentiation. Endocr Rev 1992; 13: 66-80.

31. Lind L, Wengle B, Lithell H, Ljunghall S. Reduction in serum alkaline phosphatase levels by treatment with active vitamin $\mathrm{D}$ (alphacalcidol) in primary and secondary hyperparathyroidism and in euparathyroid individuals. Scand J Urol Nephrol 1991; 25: 233-6.

32. Somjen D, Weisman Y, Kaye AM. Pretreatment with 1,25(OH)2 vitamin D or $24,25(\mathrm{OH}) 2$ vitamin D increases synergistically responsiveness to sex steroids in skeletal-derived cells. J Steroid Biochem Mol Biol 1995; 55: 211-7.

33. Long J, Liu P, Zhang Y, et al. Interaction effects between estrogen receptor alpha gene, vitamin $\mathrm{D}$ receptor gene, age, and sex on bone mineral density in Chinese. J Hum Genet 2003; 48: 514-9.

34. van Leeuwen JP, van den Bemd GJ, van Driel M, Buurman CJ, Pols HA. 24,25-Dihydroxyvitamin D(3) and bone metabolism. Steroids 2001; 66: 375-80.

35. Chen JT, Shiraki M, Hasumi K, et al. 1-alpha-Hydroxyvitamin D3 treatment decreases bone turnover and modulates calcium-regulating hormones in early postmenopausal women. Bone 1997; 20: $557-62$.

36. Hofbauer LC, Dunstan CR, Spelsberg TC, Riggs BL, Khosla S. Osteoprotegerin production by human osteoblast lineage cells is stimulated by vitamin $\mathrm{D}$, bone morphogenetic protein-2, and cytokines. Biochem Biophys Res Commun 1998; 250: 776-81.

37. Cantorna MT, Woodward WD, Hayes CE, DeLuca HF. 1,25-dihydroxyvitamin D3 is a positive regulator for the two anti-encephalitogenic cytokines TGF-beta 1 and IL-4. J Immunol 1998; 160: 5314-9.

38. Zofkova I, Kancheva RL. The effect of $1,25(\mathrm{OH}) 2$ vitamin D3 on CD4+/CD8+ subsets of T lymphocytes in postmenopausal women. Life Sci 1997; 61: 147-52.

39. Richy F, Ethgen O, Bruyere O, Reginster JY. Efficacy of alphacalcidol and calcitriol in primary and corticosteroid-induced osteoporosis: a meta-analysis of their effects on bone mineral density and fracture rate. Osteoporos Int 2004; 15: 301-10.

40. Richy F, Schacht E, Bruyere O, Ethgen O, Gourlay M, Reginster JY. Vitamin D analogs versus plain vitamin D in preventing bone loss and osteoporosis-related fractures: a comparative meta-analysis. Calcif Tissue Int 2005 (in press).

41. Hayashi Y, Fujita T. Decrease of vertebral fracture in osteoporotics by administration of 1-alpha-hydroxy-vitamin D3. JBMM 1992; 10: 184-8.

42. Menczel J, Foldes J, Steinberg R, et al. Alfacalcidol (alpha D3) and calcium in osteoporosis. Clin Orthop 1994; 300: 241-7.

43. Orimo $H$, Shiraki M, Hayashi Y, et al. Effects of 1 alpha-hydroxyvitamin D3 on lumbar bone mineral density and vertebral fractures in patients with postmenopausal osteoporosis. Calcif Tissue Int 1994; 54: 370-6.

44. Shiraki M, Kushida K, Yamazaki K, Nagai T, loue T, Orimo H. Effects of 2 years' treatment of osteoporosis with 1a-hydroxy vitamin
D3 on bone mineral density and incidence of fracture: a placebocontrolled, double-blind prospective study. Endocr J 1996; 43: 211-20.

45. Reginster JY, Kuntz D, Verdickt W, et al. Prophylactic use of alfacalcidol in corticosteroid-induced osteoporosis. Osteoporos Int 1999; 9: 75-81.

46. Sato Y, Manabe S, Kuno H, Oizumi K. Amelioration of osteopenia and hypovitaminosis D by 1a-hydroxyvitamin D3 in elderly patients with Parkinson's disease. J Neurosurg Psychiatry 1999; 66: 64-8

47. Sato Y, Maruoka H, Oizumi K. Amelioration of hemiplegia-associated osteopenia more than 4 years after stroke by 1-a-hydroxyvitamin D3 and calcium supplementation. Stroke 1997; 28: 736-9.

48. Lakatos P, Nagy Z, Kiss L, Horvath C, Takacs I, Foldes J. Prevention of corticosteroid-induced osteoporosis by alphacalcidol. Z Rheumatol 2000; 59: 48-52.

49. Aloia JF. Role of calcitriol in the treatment of postmenopausal osteoporosis. Metabolism 1990; 39 (4 Suppl 1): 35-8.

50. Ebeling PR, Wark JD, Yeung S, et al. Effects of calcitriol or calcium on bone mineral density, bone turnover, and fractures in men with primary osteoporosis: a two-year randomized, double blind, double placebo study. J Clin Endocrinol Metab 2001; 86: 4098-103.

51. Sambrook P, Henderson NK, Keogh A, et al. Effect of calcitriol on bone loss after cardiac or lung transplantation. J Bone Miner Res 2000; 15: 1818-24.

52. Gallagher JC, Riggs BL, Recker RR, Goldgar D. The effect of calcitriol on patients with postmenopausal osteoporosis with special reference to fracture frequency. Proc Soc Exp Biol Med 1989; 191: 287-92.

53. Gallagher JC, Goldgar D. Treatment of postmenopausal osteoporosis with high doses of synthetic calcitriol. A randomized controlled study. Ann Intern Med 1990; 113: 649-55.

54. Gallagher JC, Fowler SE, Detter JR, Sherman SS. Combination treatment with estrogen and calcitriol in the prevention of age-related bone loss. J Clin Endocrinol Metab 2001; 86: 3618-28.

55. Lambrinoudaki I, Chan DT, Lau CS, Wong RW, Yeung SS, Kung AW. Effect of calcitriol on bone mineral density in premenopausal Chinese women taking chronic steroid therapy. A randomized, double blind, placebo controlled study. J Rheumatol 2000; 27: 1759-65.

56. Sambrook P. Alfacalcidol and calcitriol in the prevention of bone loss after organ transplantation. Calcif Tissue Int 1999; 65: 341-3

57. Hedstrom M. Hip fracture patients, a group of frail elderly people with low bone mineral density, muscle mass and IGF-I levels. Acta Physiol Scand 1999; 167: 347-50.

58. Ritz E, Boland R, Kreusser W. Effects of vitamin D and parathyroid hormone on muscle: potential role in uremic myopathy. Am J Clin Nutr 1980; 33: 1522-9.

59. Pleasure D, Wyszynski B, Sumner A, et al. Skeletal muscle calcium metabolism and contractile force in vitamin D-deficient chicks. J Clin Invest 1979; 64: 1157-67.

60. Curry OB, Basten JF, Francis MJ, Smith R. Calcium uptake by sarcoplasmic reticulum of muscle from vitamin D-deficient rabbits. Nature 1974; 249: 83-4

61. Curry O, Francis MJ, Smith R. Proceedings: The effects of vitamin D deficiency on the isolated sarcoplasmic reticulum of muscle. Clin Sci Mol Med 1974; 46: 7P.

62. Stroder J. Hypothyroidism and rachitis. Arch Kinderheilkd [Archives of Pediatrics] 1965; 173: 105-9. 
63. Bischoff HA, Borchers M, Gudat F, et al. In situ detection of 1,25dihydroxyvitamin D3 receptor in human skeletal muscle tissue. Histochem J 2001; 33: 19-24.

64. Bischoff HA, Stahelin HB, Tyndall A, Theiler R. Relationship between muscle strength and vitamin $\mathrm{D}$ metabolites: are there therapeutic possibilities in the elderly? Z Rheumatol 2000; 59 (Suppl 1): 39-41.

65. Bischoff HA, Stahelin HB, Urscheler N, et al. Muscle strength in the elderly: its relation to vitamin D metabolites. Arch Phys Med Rehabil 1999; 80: 54-8.

66. Rimaniol JM, Authier FJ, Chariot P. Muscle weakness in intensive care patients: initial manifestation of vitamin D deficiency. Intensive Care Med 1994; 20: 591-2.

67. Buitrago C, Vazquez G, De Boland AR, Boland R. The vitamin D receptor mediates rapid changes in muscle protein tyrosine phosphorylation induced by $1,25(\mathrm{OH})(2) \mathrm{D}(3)$. Biochem Biophys Res Commun 2001; 289: 1150-6.

68. Visser M, Deeg DJ, Lips P. Low vitamin D and high parathyroid hormone levels as determinants of loss of muscle strength and muscle mass (sarcopenia): the Longitudinal Aging Study Amsterdam. J Clin Endocrinol Metab 2003; 88: 5766-72.

69. Zittermann A, Schleithoff SS, Tenderich G, Berthold HK, Korfer $\mathrm{R}$, Stehle P. Low vitamin D status: a contributing factor in the pathogenesis of congestive heart failure? J Am Coll Cardiol 2003; 41: 105-12.

70. Ziambaras K, Dagogo-Jack S. Reversible muscle weakness in patients with vitamin D deficiency. West J Med 1997; 167: 435-9.

71. Grady D, Halloran B, Cummings S, et al. 1,25-Dihydroxyvitamin D3 and muscle strength in the elderly: a randomized controlled trial. J Clin Endocrinol Metab 1991; 73: 1111-7.

72. Lips P, Graafmans WC, Ooms ME, Bezemer PD, Bouter LM. Vitamin $\mathrm{D}$ supplementation and fracture incidence in elderly persons. A randomized, placebo-controlled clinical trial. Ann Intern Med 1996; 124: 400-6.

73. Glerup H, Mikkelsen K, Poulsen L, et al. Hypovitaminosis D myopathy without biochemical signs of osteomalacic bone involvement. Calcif Tissue Int 2000; 66: 419-24.

74. Pfeifer M, Begerow B, Minne HW, Abrams C, Nachtigall D, Hansen C. Effects of a short-term vitamin D and calcium supplementation on body sway and secondary hyperparathyroidism in elderly women. J Bone Miner Res 2000; 15: 1113-8.

75. Bischoff H, Stahelin H, Dick W, et al. Effects of vitamin D and calcium supplementation on falls: a randomized controlled trial. $\mathrm{J}$ Bone Miner Res 2003; 18: 343-51.

76. Dukas L, Bischoff HA, Lindpaintner LS, et al. Alfacalcidol reduces the number of fallers in a community-dwelling elderly population with a minimum calcium intake of more than $500 \mathrm{mg}$ daily. J Am Geriatr Soc 2004; 52: 230-6.

77. Janssen HC, Samson MM, Verhaar HJ. Vitamin D deficiency, muscle function, and falls in elderly people. Am J Clin Nutr 2002; 75: 611-5.

78. O'Kelly J, Hisatake J, Hisatake Y, Bishop J, Norman A, Koeffler HP. Normal myelopoiesis but abnormal T lymphocyte responses in vitamin D receptor knockout mice. J Clin Invest 2002; 109 . 1091-9.

79. Towers TL, Freedman LP. Granulocyte-macrophage colonystimulating factor gene transcription is directly repressed by the vitamin D3 receptor. Implications for allosteric influences on nuclear receptor structure and function by a DNA element. J Biol Chem 1998; 273: 10338-48.

80. DeLuca HF, Cantorna MT. Vitamin D: Its role and uses in immunology. FASEB J 2001; 15: 2579-85.
81. Lemire JM. Immunomodulatory actions of 1,25-dihydroxyvitamin D3. J Steroid Biochem Mol Biol 1995; 53: 599-602.

82. Lemire JM, Archer DC, Beck L, Spiegelberg HL. Immunosuppressive actions of 1,25-dihydroxyvitamin D3: preferential inhibition of Th1 functions. J Nutr 1995; 125 (Suppl 6): 1704S-8S.

83. Garcion E, Sindji L, Nataf S, Brachet P, Darcy F, MonteroMenei CN. Treatment of experimental autoimmune encephalomyelitis in rat by 1,25-dihydroxyvitamin D3 leads to early effects within the central nervous system. Acta Neuropathol (Berl) 2003; 105: 438-48.

84. Oelzner P, Muller A, Deschner F, et al. Relationship between disease activity and serum levels of vitamin D metabolites and PTH in rheumatoid arthritis. Calcif Tissue Int 1998; 62: 193-8.

85. Vaisberg MW, Kaneno R, Franco MF, Mendes NF. Influence of cholecalciferol (vitamin D3) on the course of experimental systemic lupus erythematosus in F1 (NZBxW) mice. J Clin Lab Anal 2000; 14: 91-6

86. Zella JB, DeLuca HF. Vitamin D and autoimmune diabetes. J Cell Biochem 2003; 88: 216-22.

87. Froicu M, Weaver V, Wynn TA, McDowell MA, Welsh JE, Cantorna MT. A crucial role for the vitamin D receptor in experimental inflammatory bowel diseases. Mol Endocrinol 2003; 17: 2386-92.

88. Demoor-Fossard M, Galera P, Santra M, Iozzo RV, Pujol JP, Redini F. A composite element binding the vitamin $\mathrm{D}$ receptor and the retinoic $\mathrm{X}$ receptor alpha mediates the transforming growth factor-beta inhibition of decorin gene expression in articular chondrocytes. J Biol Chem 2001; 276: 36983-92.

89. Tanaka H, Abe E, Miyaura C, et al. 1 alpha,25-Dihydroxycholecalciferol and a human myeloid leukaemia cell line (HL-60). Biochem J 1982; 204: 713-9.

90. Wiese RJ, Uhland-Smith A, Ross TK, Prahl JM, DeLuca HF. Upregulation of the vitamin $\mathrm{D}$ receptor in response to 1,25 -dihydroxyvitamin D3 results from ligand-induced stabilization. J Biol Chem 1992; 267: 20082-6.

91. Yamauchi Y, Tsunematsu T, Konda S, Hoshino T, Itokawa Y, Hoshizaki H. A double blind trial of alfacalcidol on patients with rheumatoid arthritis (RA). Ryumachi [official journal of the Japan Rheumatism Association] 1989; 29: 11-24.

92. Yang S, Smith C, Prahl JM, Luo X, DeLuca HF. Vitamin D deficiency suppresses cell-mediated immunity in vivo. Arch Biochem Biophys 1993; 303: 98-106.

93. Yang S, Smith C, DeLuca HF. 1 alpha, 25-Dihydroxyvitamin D3 and 19-nor-1 alpha, 25-dihydroxyvitamin D2 suppress immunoglobulin production and thymic lymphocyte proliferation in vivo. Biochem Biophys Acta 1993; 1158: 279-86.

94. Kameda H, Takeuchi T. Osteoporosis associated with rheumatoid arthritis. Nippon Rinsho [Japonese Journal of Clinical Medicine] 2003; 61: 292-8

95. Haugeberg G, Orstavik RE, Kvien TK. Effects of rheumatoid arthritis on bone. Curr Opin Rheumatol 2003; 15: 469-75.

96. Brosch S, Redlich K, Pietschmann P. [Pathogenesis of osteoporosis in rheumatoid arthritis]. Acta Med Austriaca 2003; 30: 1-5.

97. Hirayama T, Danks L, Sabokbar A, Athanasou NA. Osteoclast formation and activity in the pathogenesis of osteoporosis in rheumatoid arthritis. Rheumatology (Oxf) 2002; 41: 1232-9.

98. Sugiyama T. Involvement of interleukin- 6 and prostaglandin E2 in periarticular osteoporosis of postmenopausal women with rheumatoid arthritis. J Bone Miner Metab 2001; 19: 89-96.

99. Joe B, Griffiths MM, Remmers EF, Wilder RL. Animal models of rheumatoid arthritis and related inflammation. Curr Rheumatol Rep 1999; 1: 139-48. 
100. Yilmaz M, Kendirli SG, Altintas D, Bingol G, Antmen B. Cytokine levels in serum of patients with juvenile rheumatoid arthritis. Clin Rheumatol 2001; 20: 30-5

101. Pascher E, Perniok A, Becker A, Feldkamp J. Effect of 1alpha, 25(OH)2-vitamin D3 on TNF alpha-mediated apoptosis of human primary osteoblast-like cells in vitro. Horm Metab Res 1999;31:653-6.

102. Bottcher J, Malich A, Pfeil A, et al. Potential clinical relevance of digital radiogrammetry for quantification of periarticular bone demineralization in patients suffering from rheumatoid arthritis depending on severity and compared with DXA. Eur Radiol 2004; 14: 631-7.

103. Goertz B, Fassbender WJ, Williams JC, et al. Vitamin D receptor genotypes are not associated with rheumatoid arthritis or biochemical parameters of bone turnover in German RA patients. Clin Exp Rheumatol 2003; 21: 333-9.

104. Lee CK, Hong JS, Cho YS, Yoo B, Kim GS, Moon HB. Lack of relationship between vitamin $\mathrm{D}$ receptor polymorphism and bone erosion in rheumatoid arthritis. J Korean Med Sci 2001; 16: 188-92.

105. Gough A, Sambrook P, Devlin J, et al. Effect of vitamin D receptor gene alleles on bone loss in early rheumatoid arthritis. $J$ Rheumatol 1998; 25: 864-8.

106. Lisker R, Lopez MA, Jasqui S, et al. Association of vitamin D receptor polymorphisms with osteoporosis in Mexican postmenopausal women. Hum Biol 2003; 75: 399-403.

107. Ravid A, Koren R, Maron L, Liberman UA. 1,25(OH)2D3 increases cytotoxicity and exocytosis in lymphokine-activated killer cells. Mol Cell Endocrinol 1993; 96: 133-9.

108. Rau R. Use of glucocorticoids in rheumatoid arthritis. Inhibition of disease progression versus risk of steroid osteoporosis. Z Rheumatol [German Journal of Rheumatology] 2001; 60: 485-91.

109. Solomon DH, Katz JN, Jacobs JP, La Tourette AM, Coblyn J. Management of glucocorticoid-induced osteoporosis in patients with rheumatoid arthritis: rates and predictors of care in an academic rheumatology practice. Arthritis Rheum 2002; 46: 3136-42.

110. Reginster JY, de Froidmont C, Lecart MP, Sarlet N, Defraigne JO. Alphacalcidol in prevention of glucocorticoid-induced osteoporosis. Calcif Tissue Int 1999; 65: 328-31.

111. Yudoh K, Matsuno H, Osada R, Nakazawa F, Katayama R, Kimura T. Decreased cellular activity and replicative capacity of osteoblastic cells isolated from the periarticular bone of rheumatoid arthritis patients compared with osteoarthritis patients. Arthritis Rheum 2000; 43: 2178-88.

112. Ohlsson C, Bengtsson BA, Isaksson OG, Andreassen TT, Slootweg MC. Growth hormone and bone. Endocr Rev 1998; 19: 55-79.

113. Ohlsson C, Vidal O. Effects of growth hormone and insulin-like growth factors on human osteoblasts. Eur J Clin Invest 1998; 28: $184-6$

114. Toyoda T, Inokuchi S, Saito S, Horie Y, Tomita S. Bone loss of the radius in rheumatoid arthritis. Comparison between 34 patients and 40 controls. Acta Orthop Scand 1996; 67: 269-73.

115. Lee S, Szlachetka M, Christakos S. Effect of glucocorticoids and 1,25-dihydroxyvitamin D3 on the developmental expression of the rat intestinal vitamin $\mathrm{D}$ receptor gene. Endocrinology 1991; 129: 396-401.

116. Godschalk M, Levy JR, Downs RW, Jr. Glucocorticoids decrease vitamin D receptor number and gene expression in human osteosarcoma cells. J Bone Miner Res 1992; 7: 21-7.

117. Blotta MH, DeKruyff RH, Umetsu DT. Corticosteroids inhibit IL12 production in human monocytes and enhance their capacity to induce IL-4 synthesis in CD4+ lymphocytes. J Immunol 1997; 158: 5589-95.

118. Schacht E. Osteoporosis in rheumatoid arthritis- significance of alfacalcidol in prevention and therapy. Z Rheumatol [German Journal of Rheumatology] 2000; 59 (Suppl 1): 10-20.

119. McKnight AJ, Zimmer GJ, Fogelman I, Wolf SF, Abbas AK. Effects of IL-12 on helper T cell-dependent immune responses in vivo. J Immunol 1994; 152: 2172-9.

120. Boonstra A, Barrat FJ, Crain C, Heath VL, Savelkoul HF, O'Garra A. 1alpha,25-Dihydroxyvitamin D3 has a direct effect on naive CD4(+) T cells to enhance the development of Th2 cells. J Immunol 2001; 167: 4974-80.

121. Andjelkovic Z, Vojinovic J, Pejnovic N, et al. Disease modifying and immunomodulatory effects of high dose 1 alpha $(\mathrm{OH})$ D3 in rheumatoid arthritis patients. Clin Exp Rheumatol 1999; 17: 453-6.

122. Brohult J, Jonson B. Effects of large doses of calciferol on patients with rheumatoid arthritis. A double-blind clinical trial. Scand J Rheumatol 1973; 2: 173-6.

123. Dottori L, D'Ottavio D, Brundisini B. Calcifediol and calcitonin in the therapy of rheumatoid arthritis. A short-term controlled study. Minerva Med 1982; 73: 3033-40.

124. Yamauchi Y, Tsunematsu T, Honda S, Hoshino T, Itokawa Y. A double blind trial of alfacalcidol on patients with rheumatoid arthritis (RA). Ryumachi [Official Journal of the Japan Rheumatism Association] 1989; 29: 11-24.

125. Hein G, Oelzner P. Vitamin D metabolites in rheumatoid arthritis: findings-hypotheses-consequences. Z Rheumatol [German Journal of Rheumatology] 2000; 59 (Suppl 1): 28-32.

126. Buckley LM, Leib ES, Cartularo KS, Vacek PM, Cooper SM. Calcium and vitamin D3 supplementation prevents bone loss in the spine secondary to low-dose corticosteroids in patients with rheumatoid arthritis. A randomized, double-blind, placebo-controlled trial. Ann Intern Med 1996; 125: 961-8.

127. Gukasian DA, Nasonov EL, Balabanova RM, Smirnov AV, Vlasova IS. Effects of alfacalcidol on mineral density of bone tissue in patients with rheumatoid arthritis. Klin Med [Clinical Medicine] 2001; 79: 47-50. 